\title{
Colourful differences: "Othemess" and image of God for Canadian feminist theologies
}

\author{
MARILYN J. LEGGE
}

\section{Introduction}

"When a human being, formed in the image of God, is made to suffer unjustly and is degraded personally, isn't this the same as degrading God? Isn't the real Christian mission, then, to recover the image of these workers as they were originally created?" ' Julia Esquivel, the courageous Guatemalan theologian, names women who struggle for justice as "Bearers of Life." In global struggles of women for full life, we find the beauty and power of women's affirmation of full personhood, of justice and dignity, of self-and-other-respect as the meaning of having been created in the image of God. These are the lifelines ${ }^{3}$ whereby we meet God as the power-to-act-each-other-into-well-being, the power of mutual relation. ${ }^{4}$

On the one hand there is theological vision and promise; on the other hand the reality of inhumanity and death. As Jon Sobrino recently

1 Cho Wha Soon, “The Meaning of Mission," in Let the Weak Be Strong: A Woman's Struggle for Justice (Maryknoll, NY: Orbis, 1987), p. 103.

2 Julia Esquivel, "Christian Women and the Struggle for Justice in Latin America," in Diana Eck and Devaki Jain, eds., Speaking of Faith: Global Perspectives on Women, Religion and Social Change (Philadelphia: New Society, 1987), p. 29.

3 This term is from Delores Williams, "Women's Oppression and Lifeline Politics in Black Women's Religious Narratives," Journal of Feminist Studies in Religion, 1 and 2 (1985): $59-71$

4 On the use of these theological terms see Carter Heyward, The Redemption of God: A Theology of Mutual Relation (Washington, DC: University Press of America, 1982), p. 6 passim; Beverly W. Harrison, in Carol Robb, ed., Making the Connections: Essay in Feminist Social Ethics (Boston: Beacon, 1985), p. 3-21, 39-41.

Marilyn J. Legge is McDougald Professor of Systematic Theology at St. Andrew's College, Saskatoon, sK S7N OW3.

Studies in Religion/Sciences Religieuses 21/1 (1992): 67-80

(c) 1992 Canadian Corporation for Studies in Religion / Corporation Canadienne des Sciences Religieuses 
remarked: "In El Salvador, we have also learned to ask ourselves what is truly human about human beings. To put it bluntly, we have learned to place under suspicion the Western understanding of the nature of humanity. . . . The ideal which is consistently held up for all people is that of 'modern man' or 'Western man'. . ." As a white, middle-class, Canadian Christian feminist I am clearly not alone in struggling with privilege and oppression, and the limitations of false universalism in theology. In other words, the dominant tradition fails to offer us a theological base on which to envision a world where all people are included. ${ }^{6}$

In the first section of this paper I will present theological resources available in the doctrine of the image of God as critically reformulated in a feminist perspective. In the second section I will focus on "otherness" as it functions in theological anthropology to deny the image of God, often in the tendency to assume an essential humanity without attention to the particularities or desires of womens lives. To address this problem I will argue that "difference" is a crucial category to employ if we are to be theologically accountable to the lives of those who are "other": those who are aboriginal or defined as racial/ethnic peoples; those who are poor; those who are gay and lesbian; those who are socialist; those who are women, especially the elderly; and those who are feminists. We can, of course, also objectify and treat ourselves as objects, as "other," and thus stand in need of conversion to ourselves as subjects of our own God-given lives, rather than remain objects of someone else's definition and design.

To create theological responses that are adequate involves committed dialogue with respect for diversity and openness to be changed ourselves. One of my primary sources for encountering differences among women is fiction, especially the voices of marginalized women.7 In the third section I will interpret selected Canadian narratives and present some of their implications for feminist theological work in Canada.

\section{Created in the image of God}

The Hebrew and Christian traditions about the image of God remind us that our destiny as persons is to become fully human in realizing our

5 See Jon Sobrino, "How My Mind Has Changed: Awakening from the Sleep of Inhu manity," The Christian Century (April 3, 1991): 364, 370.

6 For a salient discussion of feminist theologies' commitment to the excluded see Ellen Leonard, "Experience as a Source for Theology," Studies in Religion/Sciences Religieuses, 19 (1990): 143-62.

7 This paper presumes a broader argument which claims that genuine contextual theoogies capable of concretely naming sin and sources of hope, and of moving us to fuller participation in claiming responsibility for our lives-in-relation, will emerge from participation in claiming responsibility for our lives-in-relation, will emerge from
attention to both struggles for cultural sovereignty and struggles for economic justice in national and global spheres. See Marilyn J. Legge, The Grace of Difference: A Canadian Feminist Theological Ethic (Atlanta: Scholars Press, forthcoming). 
co-creator status. Dorothee Soelle affirms that the basis for reverence and trust in the world at the heart of Jewish-Christian faith is our reliance on sharing the power of God who is the source of all that is. Hence, against the theological pessimism of much protestant anthropology, we search for ways not to despise our experience but to claim the gift of life. ${ }^{8}$

The first basepoint or methodological step of a feminist doctrine of the image of God is that we are created by God as good and free to be moral agents. We become human-that is we image God-when we claim our freedom and share power responsibly. Freedom, then, is the power as selfrespecting, other-regarding persons to name and shape our world. In feminist theology and ethics the category of full moral agency best describes the work of co-creation. According to Bruce Birch and Larry Rasmussen, moral agency

is a way to name that which is necessary to make sense of ourselves as creatures who act "morally." It is a tag for describing human experience, and especially human action, from a moral point of view. It means we are those kinds of creatures who are able to perceive various courses of action, weigh them with a view to various considerations, and act on the basis of the considerations, and act on the choices. It also means we can be held accountable for our choices and actions. "Agency" encompasses both character and conduct, both our moral "being" and our moral "doing." ...9

As creatures in the image of God who creates life, we live most creatively as full moral agents in the holistic venture to live as self-and-communitydefinings, morally accountable persons.

To engage in the historical project of becoming a fully human person, one needs power-for feminists this is often referred to as empowerment, a form of creativity of building up oneself in community. In theological terms, power is the capacity to act with God, to fully exercise our moral agency with respect for the created order. To many trained in moral theory, however, several assumptions outlined here may he unfamiliar in my treatment of moral agency as central to being created in the image of God.

Moral agency as presented here is not co-terminous with an individual. Moral agency is based on the inestimable value of human persons and their sustainable environments, ${ }^{10}$ and aims at the enhancement of personhood, that is, the power for responsible self-direction which is most fully 8 Dorothee Soelle, Thinking About God (London: SCM Press; Philadelphia: Trinity Press International, 1991), p. 42-45.

9 Bruce Birch and Larry Rasmussen, Bible and Ethics in Christian Life, rev. ed. (Minneapolis: Augsburg Press, 1989), p. 40.

10 Douglas John Hall advances a relational understanding of imago dei as a process and a struggle, based on eschatological promises of God for restored humanity and healed creation, to image the Creator; see Imaging God: Dominion as Stewardship (Grand Rapids: Eerdmans; New York: Friendship Press, 1986), p. 65ff. 
expressed in the creation of community. Hence the liberation of persons is reciprocally related to both the goodness of creation and to deepened community. In short, to be created in God's image means that "[my] creative power is my power to renew the world for someone or for a community. Through it I attempt to rebuild the house of life out of the ruins in which we now live." 11

The second basepoint of a feminist doctrine of the image of God deals forthrightly with our human capacity for sin, i.e., breaking the image of God. Traditionally, sin has been defined as alienation from God, the state of being opposed to God, the loss of a bond or a root as the result of the misuse of human freedom. In a liberationist understanding we include alienation from God, self, neighbour and creation itself. Everywhere we look it is plain to see that people are not treated as images of God. People who are labelled as "other" suffer from marginalization because they are socially excluded from power, resources and honour. They experience victimization because of the principal evil in society: injustice. ${ }^{12}$ Dehumanization and loss of conditions to create full life are therefore evil. In feminist theology and ethics a crucial task is to uncover the massive social denial and distrust of women's moral agency. ${ }^{13}$

The third basepoint in this feminist reconstruction attends to grace as the work of co-creation, i.e., becoming and keeping life human in sustainable relations with the entire created order. The sin of injustice destroys this human vocation of being created for freedom and responsibility, and various forms of interlocking oppressions operate in direct contradiction to a theology of active engagement as co-creators in nature/history. The radicalness of human evil can be overcome only if we join together with God to reshape our social relations, our institutions and our cultures to realize our oeco -humanity.

Traditionally such deliverance from sin or the healing of the separation from God, neighbour and self is called grace or salvation. Central to the content of salvation for women and other marginalized groups is justice. Hence, a contemporary expression for grace must be acting in solidarity for justice: the cultivation of full humanity through resisting evil and aiming at concrete justice by actively recognizing the uniqueness, value and interconnectedness of all life. We image God when we claim our own creative power for life, when we learn to recognize each others' problems

11 Dorothee Soelle with Shirley Cloyes, To Work and To Love: A Theology of Creation (Philadelphia: Fortress Press, 1984), p. 37.

12 Gregory Baum theologically connects marginalization and social injustice in this way; see his "Three Theses on Contextual Theology," The Ecumenist, 24 (May-June 1986): 54.

13 Kathryn Pauly Morgan brilliantly discusses four manoeuvres in ethical theory and moral practice that deny women's moral agency in "Women and Moral Madness," Canadian Journal of Philosophy, Supplementary Volume 13 (1983): 210-26. 
and possibilities as the interconnecting basis for solidarity, and when we live into a future in which all persons can be whole. In short, we will glean the theological significance of women's experience when, in God's image, we struggle against conditions which crucify and perpetuate injustice, when we find God as liberating and empowering presence who encourages us to co-operate as subjects in our own destinies. Thus in this formulation the transcendence of God does not lie in some abstract aseity of a creator outside the world, nor is it forgotten in a collapsed immanence, as often in liberal theology, but the transcendence of God, we discover, comes alive in the social praxis of those who as co-creators refuse complicity in deathdealing patterns of social relations and resist those structural dynamics that perpetuate life-denying conditions.

The commitment to struggle against oppressive conditions of dependency, invisibility and exploitation, and to join others in shaping a different world, traditionally envisioned as "the kingdom of God," is born out of the painful struggle to take our lives seriously and to claim rightful responsibility for them. The central agenda for feminist theologies and ethics, then, is attention to the specificity of women's experiences. In order to further the work of a liberative praxis it is necessary to privilege and to hear the voices of those most often silenced and denied. Karen Lebacqz insists on this epistemological position: "If justice begins with the correction of injustices, then the most important tools for understanding will be the stories of injustice as experienced by the oppressed and the tools of social and historical analysis that help illumine the process by which those historical injustices arose and the meaning of them in the lives of the victims." 14 The call for a dialogue between our own stories of suffering and hope and the stories of those on the margin has come from those who experience invisibility.

\section{Otherness and social location: Structural difference ${ }^{15}$}

We are made invisible in the mainstream. And there is talk about "coming from the woman's perspective, coming from the woman's standpoint." It seems to me very empty, this standpoint, because I do not know who this woman is that they are talking about. ${ }^{16}$

14 Karen Lebacqz, Justice in an Unjust World: Foundations for a Christian Approach to Injustice (Minneapolis: Augsburg, 1987), p. 150.

15 See Joan Borsa, "Towards a Politics of Location: Rethinking Marginality," Canadian Woman Studies/Les Cahiers de la Femme, 11 (1990): 36-39; Adrienne Rich, "Notes Towards a Politics of Location" (1984), in Blood, Bread and Poetry: Selected Prose, 1979-1985 (New York: W. W. Norton, 1986), p. 210-32.

16 Himani Bannerji, "We Appear Silent to People Who Are Deaf to What We Say," Fireweed: Issue 16, Women of Colour (May 1983): 9. 
[T]he paradox at the heart of feminism: Any attempt to talk about all women in terms of something we have in common undermines attempts to talk about differences among us, and vice versa. Is it possible to give the things women have in common their full significance without thereby implying that the differences among us are less important?'17

This is the problem for feminist theologies: to attend to the category of human experience in ways that adequately indicate who we are in all our relational power and how women under quite different circumstances have been able to shape and name our lived-world contexts. We must, then, remember that all theological claims about divine-human relation are simultaneously claims about our social relations and therefore have social consequences.

The insistence on similarities among us - by theological anthropologies which are based on an ahistorical, acultural, disembodied essential humanity - functions to deny actual relations of domination and subordination and serves to perpetuate the invisibility of many people's lives. "In God's image" is adopted by many feminist Christians to help define our perspective on the meaning of being human. ${ }^{18}$

In feminist liberation theologies, concepts of divine-human relation are based on the norm of women as complete, fully valuable moral persons in their own right. This norm must be tested by a functional criterion and with concrete reference, however, if we are truly to embrace our lives as created in God's image. As womanist theologian Delores Williams advocates: “. . we must now evaluate the social effect of the images and rituals central to the Christian religion and search our tradition for those that foster healing rather than brutality." 19 Sin and salvation are not abstract categories empty of particular content. Without specifying the conditions in which women can hope to live as centred, rightly related persons, women's lives will continue to he distorted and further damaged. Thus if we are to build theologies sturdy enough to specify and account for women's varied and complex oppressions and sources of hope, difference or relational particularity must be a pivotal category in moral theological discussions truly committed to naming and resisting sin and participating in salvation. As I will now discuss, difference can function as a critical exposer of uneven power relations in our lives as well as a gift to be embraced and shared.

17 Elizabeth Spelman, Inessential Women: Problems of Exclusion in Feminist Thought (Boston: Beacon, 1988), p. 3.

18 For a most helpful interpretation of Asian feminist theological treatments of the image of God theme, see Chung Hyun Kyung, Struggle to Be the Sun Again: Introducing Asian Women's Theology (Maryknoll, NY: Orbis, 1990), p. 36-52.

19 Delores Williams, "Humans Brutalizing Humans: Necessary Images in the Christian Religion?," Women's Theological Center Quarterly Newsletter, 9 (March 1991): 2. The term womanist is adopted from Alice Walker, In Search of Our Mothers' Gardens: Womanist Prose (San Diego: Harcourt Brace Jovanovich, 1984), p. xixii. 
In Genesis 1:27 difference in the image of God as male and female is affirmed. Feminists have also emphasized the embodied connection with God in our moral struggles for justice and love where we meet God as the visceral connecting power who empowers and sustains us. Some feminists also recognize in theory the distinction between the female sex as a biological category and the socially constructed category of "woman" which varies across histories and cultures. But in thinking of my Christian co-religionists, however, I find we have a long way to go before difference as male and female in the image of God is appreciated; we are even further from a theological anthropology that teaches that we are not simply generic female or male.

Those of us who define ourselves as feminists do so because the social relations we experience-including the church-call for struggle, analysis, change and celebration along the "unbeaten path" if we are to become fully human. ${ }^{20}$ However, just because we become conscientized and active in struggles for transformation does not mean we automatically eradicate the contradictions of our everyday lives. Instead, we must come to accept the presupposition that our own particular stance, whatever it is, is not pre-ordained or normative, but is itself the product of many factors that may heretofore have escaped our notice. Once identified with the shifting, complex terrain of feminism one will soon be plagued by what is referred to in feminist theory and theologies as social location or what Canadian cultural critic Joan Borsa calls "the politics of location":

... those places and spaces we inherit and occupy, which frame our lives in very specific and concrete ways, which are as much a part of our psyches as they are a physical or geographical placement. Where we live, how we live, our relation to the social systems and structures that surround us are deeply embedded parts of everything we do and remain integral both to our identity or sense of self and to our position or status within a larger cultural and representational field. While many of us are active in feminism, [in religious practice], in cultural production and in critical social theory [and theology], our historical, social, political and economic realities vary-there is a great deal of structural difference between us. ${ }^{21}$

Given the historical specificity of our social location we can see that one is never "naturally" consigned to a particular space, even if we are otherwise informed by ideologies that systematically utilize difference as a tool for domination by teaching that certain groups, by virtue of their difference, "naturally" have particular power and privilege.

While structures of difference (e.g., race or ethnicity, culture, dass, physical ability, age, sexual preference and gender) have distinctive manifestations and combinations, the point is to construe their relevance for

20 "The Unbeaten Path" is the name of the Saskatchewan Christian Feminist Network newsletter, available from 418A McDonald St., Regina, SK S4N 6E1.

21 Borsa, "Towards a Politics of Location," p. 36. 
the best possible strategies of social transformation, and to avoid dogmatic assigning of timeless priorities. An awareness of our own social location can liberate us from seeking to exercise over others a kind of theological imperialism. Thus, self-critical awareness and deepened historical understanding of the structures of race, sexuality, class, culture and gender are enhanced by attention to difference.

Because "all difference is not the same difference," 22 a key challenge in our work as feminist theologians and ethicists is to name our social locations and to question where our particular experiences of power, privilege and oppression (along with our practices) fit within current social relations. For example: How is the agenda for feminist theology set? Who is included in our work and to whom are we accountable? How does our access to resources for shaping our own lives affect the way we relate to the church and our broader social and cultural context?

When feminists refuse to take difference among women seriously we become complicit in a politics of domination. Because of the structural contradictions that shape difference, however, both the assertion of dif ference and the denial of difference can operate on behalf of domination. In exploring how difference functions to objectify and negate the other, the work of Canadian philosopher Susan Wendell is particularly helpful. She observes:

When we make people "other," we group them together as the objects of our experience instead of regarding them as fellow subjects of experience with whom we might identify. If you are "other" to me, I see you primarily as symbolic of something else-usually, but not always, something I reject and fear and that I project onto you. We can all do this to each other, but very often the process is not symmetrical, because one group of people may have more power to call itself the paradigm of humanity and to make the world suit its own needs and validate its own experiences. For example, disabled people are "other" to able-bodied people, and ... the consequences are socially, economically and psychologically oppressive to the disabled, and psychologically oppressive to the able-bodied. Ablebodied people may he "other" to disabled people, but the consequences of this for the able-bodied are minor (most able-bodied people can afford not to notice it). ${ }^{23}$

Because the privilege some women have is at the expense of others and thus damages both those who have it and those who are deprived, albeit in different ways, we must do much more than simply note the presence of difference-we must study and learn to recognize how it distorts our humanity and struggle to overcome our varied positions of out siderhood. ${ }^{24}$ While women are subordinated in different ways, they may

22 Ruth Smith, "The Evasion of Otherness: A Problem for Feminist Moral Reconstruc tion," Union Seminary Quarterly Review, 43 (1990): 151.

23 Susan Wendell, “Towards a Theory of Disability," Hypatia, 4 (1989): 112.

24 This term is from Cherrie Moraga, Loving in the War Years (Boston: South End Press, 1983). 
have some similar constraints on their moral agency under particular historical conditions - for example, women, despite their differences, are more vulnerable to violence. ${ }^{25}$ Hence we must resist both a simple acceptance and a rejection of the differences among women. Instead, we will aim to empower each woman to specify the particularities of her own life, to learn the causes of her sufferings and to name the sources of her hope.

We must, therefore, both name the real divisions among us and simultaneously approach differences and the other with the hope of seeking interdependent, nondo minant, creative difference which offers what poet Audre Lorde calls a "raw and powerful connection from which our personal power is forged." 26 Lorde admonishes us to recognize the gross limits of advocating mere tolerance of difference among women. A better route to discovering our authentic power/presence as human beings is to cultivate our differences as well as our similarities within communities of accountability. This commitment, I believe, requires that moral theologians define and empower cultural differences as the groundwork for common political strategies, action for justice and ritual embodiment.

\section{Canadian resources for identifying otherness and difference}

I have asserted that the feminist theological agenda must learn to honour difference, to study and respect the varied positions of outsiderhood women as "others" are inscribed within, and also to struggle for, but not assume, common ground in working for justice. It is legitimate, therefore, to ask how the needs central to my liberation (e.g., work, safe space, friendships, housing, religious practice) take form and come to expression in the lives of those who are doubly or triply oppressed? Accountability to race and class and the texture of specific cultures enables this dialogue. While we do not possess familiarity with contexts different from ours, we must find new ways of listening and learning. One readily available resource is Canadian fiction by marginalized women which focusses on what, in a theological frame, we can link with studies of women embracing their lives as created in the image of God.

I have read Canadian fiction to discover Canadian and personal narratives that give power to "the other" and to the creative spark of difference, narratives that offer a different and specific content to the meaning of the human person as created in the image of God. I have chosen three prairiebased novels. Beatrice Culleton's In Search of April Raintree ${ }^{27}$ is a

25 For an elaboration of this point see Thistlethwaite, Sex, Race, and God: Christian Feminism in Black and White (New York: Crossroad, 1989), p. 126-43.

26 Audre Lorde, Sister Outsider: Essays and Speeches (Trumansburg, NY: The Crossing Press, 1984), p. 111-12.

27 Beatrice Culleton, In Search of April Raintree (Winnipeg: Pemmican, 1983). 
clearly rendered Métis point of view and a monumental breaking of the silence about her people's struggle for life; Joy Kogawa is a powerful Japanese-Canadian literary voice who depicts in Obasan ${ }^{28}$ her people's spirit and effort to survive with dignity; and Margaret Laurence's The Diviners, ${ }^{29}$ the last in her Manwaka series about women's struggles to create themselves, is a skilful story told from within a white prairie culture. The three narratives signify how their respective protagonists, April Raintree, Naomi Nakane and Morag Gunn, become persons when they resist various assaults on their moral agency by coming to terms with their ancestors, the land and creation, and their own places as assertive, interdependent women in particular social histories.

I have argued for the need to attend to concrete differences in women's lives as a source for theological knowledge. I will now briefly offer a theological interpretation of the novels according to the three themes of moral agency, sin and grace outlined for a feminist doctrine of the image of God.

Theologically, the novels depict the spiritual struggles of their protagonists to move into their own creative power. We learn from them to appreciate that sacred power is known in the immediacy of human love, in relationships which affirm and give space to grow when chaos or oppression is the norm. We can name the relationships of Morag and her lover Jules Tonnere, April and her sister Cheryl, Naomi and her aunts. Never do these women meet sacred power by denying someone else's personhood. Moral agency is portrayed as the integration of the many dimensions that compose personhood which, according to Allison Maul Moore, is based on two prerequisites: "a minimal level of self-respect (the ability to believe in one's own intrinsic worth) and self-assertion (the ability to trust one's own abilities enough to identify and ask for what one needs). . . ."30

While each protagonist takes responsibility for her own life, it is never without great cost. All three suffer deeply, often through inherited injus tice of being born of aboriginal, Japanese, or poor and disinherited ancestry. We are not spared seeing, hearing and feeling the fears and agonizing doubts, the nightmares and abuse which characterize their stories. Sin is aptly portrayed as muteness, the absence of the power to interpret rightly, sometimes as acceptance of isolation, self-denial or the failure to have courage and risk a different route. Without endorsing pain and suffering as salvific in and of itself, the authors nonetheless have

28 Joy Kogawa, Obasan (Toronto: Lester and Orpen Denys, 1981; reprinted Markham, ON: Penguin, 1982).

29 Margaret Laurence, The Diviners (Toronto: McClelland and Stewart, 1974; reprinted New York: Bantam, 1982).

30 Allison Mauel Moore, "Moral Agency of Women in a Battered Women's Shelter," in Dianne Yeager, ed., The Annual of the Society of Christian Ethics, 1990 (Washington, DC: Georgetown University Press, 1990), p. 131. 
dwelt on how the struggle towards authentic human life goes through, not around, their deepest sorrow and suffering.

Sin is also identified as the corporate abuse of power that oppresses whole groups of people. Corporate sin in the novels denies to women, Métis, Japanese, artists and poor working Canadians the possibility of communal self-creation. In short, sin is portrayed as that which brings death to the people's resources for creation and abundant life.

The characters' failures to realize their own freedom is not simply their own fault. Sin is that which brings about death in relationships among people or to the land. The narratives, therefore, portray their protagonists as those who are also sinned-against. In other words, while the characters' hopes for full life were at times thwarted by their own passivity, their inner resolve developed through a deepening understanding of their own histories and their attempts to exorcise the internalized self-hate for which they come to realize they are not responsible.

In each novel we are shown that suffering has no meaning unless it is freely chosen for a greater good. The only meaning that can be ascribed to the brutal pain experienced by the destruction of April's and Naomi's peoples is in their choice to resist oppression and confront abuse. The different circumstances of their lives lead them to search for different expressions of freedom and spiritual life - April is raised as a Japanese alien in an internment camp and becomes a teacher; Naomi, of Métis ancestry with a troubled upbringing, finds work as a secretary; Morag grows up in the home of the town scavenger and struggles to survive as a writer.

In Kogawa's metaphor, the search is for the freeing word, the living word from the stone of silence. Near the close of Obasan she names that word as "love," the power to break silence in her own heart and the lives of her people. In Culleton, the search for belonging and respect, for spiritual power and a future for the children of mixed cultures, the symbol of transformation of suffering is in April's sister Cheryl: "[She] was that stalk in the field of grain which never bent to the mighty winds of authority. At the same time, that stalk could bend to the gentle breezes of compassion." 31 Grace for April and Naomi is the resistance to deforming definitions of their lives.

For Laurence, the symbol for Morag's learning to live by her own approval and creativity in community is the art of divining, whether for water or discernment. Her search for submerged histories in Scotland and the prairies, and for transforming, life -giving values to pass along to the next generation, is nourished by her commitment to embrace her own life seriously and cherish her gifts for divining. The rare Blue Heron is Laurence's symbol of transcendence whose soaring measured flight is as 
certain as the promise of righteousness in relationships when people learn to live into grace and embrace life as both a task and a gift.

Salvation must be specifically named in relation to characters who struggle for survival on the edges of society. For resurrection to happen, for the promise of right-relationship to be fulfilled, all three novelists identify particular stones which their protagonists must roll away: the heaviest ones include economic dependence, broken family bonds and lifeless marriages, ignorance and stultifying self-images.

The narratives depict responses to the unspeakable adversity and distortion of human life. Often the characters face choices between relative deprivations (as April, Naomi and Morag did in "choosing" to stay in deadening jobs or relationships) and the huge risk of uncharted paths of survival. These characters are women who come into their co-creative power by struggling to embrace life through confrontations with otherness and with their own nothingness. In them we encounter creative power as the power to save from apathy and denial and to trust the goodness in an often hostile world.

Each protagonist also learns that evil is only resisted or undone by taking courage and claiming her life as hers to live, despite the limits on and violations of her agency. Each moves onto sacred ground in those moments when she organizes her life with what we who practise a Chris tian faith would name the power of the Holy Spirit. These women's deepest and active joy is depicted in epiphanies of thanksgiving and loveApril with her new nephew or at the Pow Wow, Naomi on the prairie communing with her mother, or Morag writing by the river, happy to be alive.

All three characters differently discover their passion for life and what it means to sustain it. It is no accident, however, that Culleton, Kogawa and Laurence portray salvation as a process involving the total well-being of creation. Their narratives offer us images of faith necessary to envision each person and all peoples as created in the image of God. For those whose lives have been slashed and scarred by subjugation, exploitation and oppression, salvation is liberation, social and spiritual, personal and physical.

In these narratives we find fictional portrayals of women empowered into moral agency, who can even at times shape conditions for freedom. In the process of surviving and creating themselves, they discover spiritual empowerment and a knowledge of rightness and belonging in themselves and among people, especially their own roots. In this struggle, they come to know a power which is beyond themselves, but which is present through their everyday struggles. Above all these protagonists teach us that God is known when we are most fully present to ourselves through self-and-other respect and in conditions that provide the communal conditions to s ustain empowering social relations. We are thereby 
related to one another, belly-wise, as Naomi was to her mother. If we read these stories as spiritual odysseys, grace is experienced as that fulfilling dimension of learning to "breathe out loud" in safety and hope.

\section{Conclusion}

"I choose to preserve myself: my sense of humanity is violated if another human being is offended. Hope . . . is a promise that things will be different for women of colour." 32 The notion of otherness as constructed in large part by structural difference has been presented as crucial to the justice agenda of feminist theologies. The concept of difference is necessary to demystify the way theology, culture and society are frequently presented as static givens, as already created and pre-ordained and therefore unchangeable.

As witnessed in a feminist reconstruction of the meaning of the human person as created in the image of God, we human beings have a definite role in fulfilling creation. As Native Canadian Lee Maracle states, our very humanity is intimately related to the well-being of one another and hope has definite features. While we have inherited a past and are born into specific configurations of an historical moment, we are, theologically speaking, both created and in the process of creating, of becoming cocreators with God.

In Jesus of Nazareth Christians recognize the incarnation of what it means to be human: to love God in loving the victims with a strong and a tender love, to love our neighbours as ourselves. Jesus' humanity manifests God's presence by his radical transformation of relationships whereby he valued each person as an image of God by sharing the power of life. Neither Jesus' life nor God's action as creator, however, in any way reduces our responsibility for living into our own power as co-creators. As it was for Jesus, our task as persons created in the image of God is to make and keep life human. Thus, to affirm the historical contingencies of our own social location does not mean embracing fatalistic despair in the face of inherited fixed systems; neither can we assume a superficial stance towards change. Instead, in response to the dehumanization of injustice - of moral evil-I join those who believe we best live our faith as pilgrims inspired by the quest of justice for all.

If we are not to despise our experience as a locus for God's embrace or to remain blind to those who pay the cost for maintaining an ahistorical generic doctrine of humanity, we will search for intimations of well-being even as we struggle against human refusals of the concrete and particular good. We have acknowledged here that difference can signify both actual 
division between women in terms of constraints on moral agency and also in the construction of fruitful common ground based on shared struggles for justice. Let us do so cautiously, however, taking heed of feminist theorist Bell Hooks' clarification: solidarity is not the same as support. That is, to experience solidarity we must have a community of interest. 33

Instead of denying otherness and difference in our theological work we can offer concrete expressions of our specific experience, learn to question the social location we occupy and to identify who our people are and who we are committed to working with. As we attempt to live faithfully by acts of resistance and renewal, I cite in closing Ruth Smith's moving insight: "To think about otherness requires that we who make theory slow down our thoughts, stretch out the race to analysis, loosen our grip on the answer, assume an attitude of humility." 34

33 See Bell Hooks, Feminist Theory: From Margin to Center (Boston: South End Press, 1984) and Talking Back: Thinking Feminist, Thinking Black (Boston: South End Press, 1989), and Uma Narayan, "Working Together Across Difference: Some Considerations on Emotions and Political Practice," Hypatia, 3 (1988): 31-47. 34 Smith, "The Evasion of Otherness," p. 147. 